\title{
ANALISIS SISTEM PROTEKSI ARUS LEBIH PADA PENYULANG CENDANA GARDU INDUK BUNGARAN PALEMBANG
}

\author{
Abdul Azis ${ }^{1}$ dan Irine Kartika Febrianti ${ }^{2}$ \\ Program Studi Teknik Elektro, Fakultas Teknik, Universitas PGRI Palembang \\ Email: ${ }^{1}$ azis@ univpgri-palembang.ac.id, ${ }^{2}$ irinekf@univpgri-palembang.ac.id
}

\begin{abstract}
Abstrak Sistem proteksi merupakan pengaman listrik pada sistem tenaga listrik yang terpasang pada sistem distribusi tenaga listrik, transformator tenaga, transmisi tenaga listrik dan generator listrik yang dipergunakan untuk mengamankan sistem tenaga listrik dari gangguan listrik atau beban lebih, dengan cara memisahkan bagian sistem tenaga listrik yang terganggu. Salah satu sistem proteksi pada sistem tenaga listrik adalah Relai Arus Lebih merupakan peralatan yang mensinyalir adanya arus lebih, baik yang disebabkan oleh adanya gangguan hubung singkat yang dapat merusak peralatan sistem tenaga listrik yang berada dalam wilayah proteksinya. Relai arus lebih ini digunakan hampir pada seluruh pola pengamanan sistem tenaga listrik, dan dapat juga digunakan sebagai pengaman utama ataupun pengaman cadangan. Dari hasil penelitian diperoleh hasil bahwa besarnya arus gangguan hubung singkat dipengaruhi oleh jarak titik gangguan, semakin jauh lokasi gangguan maka arus gangguan hubung singkat akan semakin kecil, begitu pula sebaliknya. Waktu kerja relai di sisi penyulang lebih cepat dibandingkan dengan waktu kerja di incoming dengan selisih waktu rata-rata sebesar 0,55 detik. Hal ini disebabkan lokasi gangguan mempengaruhi besar kecilnya selisih waktu. Semakin jauh jarak lokasi gangguan, maka semakin besar selisih waktu kerja relai di incoming.
\end{abstract}

Kata Kunci: Proteksi, Arus Lebih, Relai

\begin{abstract}
Protection system is an electric safeguard on an electric power system that is installed on an electric distribution system, a power transformer, an electric power transmission and an electric generator that is used to secure the electric power system from electrical disturbances or overload, by separating disrupted parts of the power system. One of the protection systems in an electric power system is Overcurrent Relays are equipment that indicates an overcurrent, both caused by a short circuit interruption that can damage the electrical power system equipment that is in its protection area. This overcurrent relay is used in almost all security patterns of the electric power system, and can also be used as a main safety or backup security. From the research results obtained that the magnitude of the shortcircuit fault current is affected by the distance of the point of disturbance, the farther the location of the fault, the short-circuit fault current will be smaller, and vice versa. Relay working time on the feeder side is faster than the incoming work time with an average time difference of 0,55 seconds. This is due to the location of the disruption affecting the size of the difference in time. The farther the distance of the disturbance location, the greater the difference in relay working time at incoming.
\end{abstract}

Keywords: Protection, Overcurrent, Relay

\section{PENDAHULUAN}

Sistem proteksi adalah suatu sistem pengamanan terhadap peralatan listrik, yang diakibatkan adanya gangguan teknis, gangguan alam, kesalahan operasi, dan penyebab yang lainnya. Sistem proteksi merupakan pengaman listrik pada sistem tenaga listrik yang terpasang pada sistem distribusi tenaga listrik, transformator tenaga, transmisi tenaga listrik dan generator listrik yang dipergunakan untuk mengamankan sistem tenaga listrik dari gangguan listrik atau beban lebih, dengan cara memisahkan bagian sistem tenaga listrik yang terganggu. Sehingga sistem kelistrikan yang tidak terganggu dapat terus bekerja (mengalirkan arus ke beban atau konsumen). Jadi pada hakekatnya pengaman pada sistem tenaga listrik yaitu mengamankan seluruh sistem tenaga listrik supaya kehandalan tetap terjaga [1].

Gangguan arus lebih ditandai dengan terjadinya kenaikan arus pada saluran melebihi arus beban maksimum. Arus lebih ini sendiri terbagi menjadi arus beban lebih dan arus hubung singkat. 
Arus beban lebih terjadi akibat penambahan beban yang akan menyebabkan kenaikan arus melebihi arus beban maksimum. Kenaikan arus ini tidak terlalu besar sehingga sistem masih bisa bertahan untuk selang waktu yang cukup lama. Sedangkan arus hubung singkat terjadi akibat penurunan kekuatan dasar isolasi dari sistem tenaga. Penurunan kekuatan isolasi ini dapat terjadi antar saluran fase atau antara saluran fase dengan tanah. Akibatnya akan timbul arus yang jauh melebihi arus beban maksimum. Sistem tenaga tidak dapat bertahan lama apabila arus gangguan hubung singkat ini tidak segera diatasi. Salah satu peralatan yang berfungsi untuk memproteksi peralatan listrik terhadap arus lebih yang disebabkan oleh gangguan hubung singkat adalah Relai Arus Lebih atau yang lebih dikenal dengan Over Current Relay (OCR). Relai Arus Lebih digunakan sebagai proteksi cadangan lokal pada proteksi penghantar, dan digunakan untuk mengamankan penghantar dari gangguan fase-fase. Untuk mengetahui sistem proteksi arus lebih pada sistem distribusi tenaga listrik, maka akan dilakukan penelitian mengenai Sistem Proteksi Arus Lebih Pada Penyulang Cendana Gardu Induk Bungaran Palembang.

\section{TINJAUAN PUSTAKA}

\section{Umum}

Sistem proteksi adalah suatu sistem pengamanan terhadap peralatan listrik, yang diakibatkan adanya gangguan teknis, gangguan alam, kesalahan operasi, dan penyebab yang lainnya. Sistem proteksi merupakan pengaman listrik pada sistem tenaga listrik yang terpasang pada sistem distribusi tenaga listrik, transformator tenaga, transmisi tenaga listrik dan generator listrik yang dipergunakan untuk mengamankan sistem tenaga listrik dari gangguan listrik atau beban lebih, dengan cara memisahkan bagian sistem tenaga listrik yang terganggu. Sehingga sistem kelistrikan yang tidak terganggu dapat terus bekerja (mengalirkan arus ke beban atau konsumen). Jadi pada hakekatnya pengaman pada sistem tenaga listrik yaitu mengamankan seluruh sistem tenaga listrik supaya kehandalan tetap terjaga [1].

Sistem proteksi merupakan suatu cara untuk mencegah atau membatasi kerusakan peralatan tehadap gangguan, sehingga kelangsungan penyaluran tenaga listrik dapat dipertahankan. Sistem proteksi penyulang tegangan menengah adalah pengamanan yang terdapat pada sel-sel tegangan menengah di Gardu Induk dan pengaman yang terdapat pada jaringan tegangan menengah. Penyulang tegangan menengah ialah penyulang tenaga listrik yang berfungsi untuk mendistribusikan tenaga listrik tegangan menengah $(6 \mathrm{kV}-20 \mathrm{kV})$, yang terdiri dari: Saluran Udara Tegangan Menengah (SUTM), dan Saluran Kabel Tegangan Menengah (SKTM) [5].

\section{Ganguan Hubung Singkat}

Gangguan hubung singkat adalah gangguan yang terjadi karena adanya kesalahan antara bagian-bagian yang bertegangan. Gangguan hubung singkat dapat juga terjadi akibat adanya isolasi yang tembus atau rusak karena tidak tahan terhadap teganggan lebih, baik yang berasal dari dalam maupun yang berasal dari luar (akibat sambaran petir). Gangguan hubung singkat dapat terjadi dua fase, tiga fase, satu fase ke tanah, dua fase ke tanah, atau 3 fase ke tanah. Gangguan hubung singkat ini sendiri dapat digolongkan menjadi dua kelompok yaitu gangguan hubung singkat simetri dan gangguan hubung singkat tak simetri (asimetri). Gangguan yang termasuk dalam hubung singkat simetri yaitu gangguan hubung singkat tiga fase, sedangkan gangguan yang lainnya merupakan gangguan hubung singkat tak simetri (asimetri). Gangguan ini akan mengakibatkan arus lebih pada fase yang terganggu dan juga akan dapat mengakibatkan kenaikan tegangan pada fase yang tidak terganggu [3].

1. Gangguan Hubung Singkat 3 Fase 
Gangguan hubung singkat tiga fasa termasuk dalam klasifikasi gangguan simetris, dimana arus maupun tegangan stiap fasanya tetap seimbang setelah gangguan terjadi. Sehingga pada sistem seperti ini dapat dianalisa hanya dengan menggunakan urutan positif saja.

2. Gangguan Hubung Singkat 2 Fase

Gangguan hubung singkat dua fasa atau yang biasa disebut hubung singkat fasa ke fasa adalah kondisi dimana antara fasa ke fasa saling terhubung singkat. Pada gangguan hubung singkat fasa ke fasa, arus saluran tidak mengandung komponen urutan nol dikarenakan tidak ada gangguan yang terhubung ke tanah.

3. Gangguan Hubung Singkat 1 Fase Ke Tanah

Gangguan hubung singkat 1 fase ke tanah yang sering terjadi pada sistem tenaga listrik merupakan gangguan asimetris sehingga memerlukan metode komponen simetris untuk menganalisa tegangan dan arus pada saat terjadi gangguan. Gangguan yang terjadi dapat dianalisa dengan menghubung-singkatkan semua sumber tegangan yang ada pada sistem dan mengganti titik (node) gangguan dengan sebuah sumber tegangan yang besarnya sama dengan tegangan sesaat sebelum terjadinya gangguan di titik gangguan tersebut. Dengan menggunakan metode ini sistem tiga fasa tidak seimbang dapat direpresentasikan dengan menggunakan teori komponen simetris yaitu berdasarkan komponen urutan positif, komponen urutan negatif, dan komponen urutan nol.

\section{Relai Arus Lebih}

Relai Arus Lebih atau yang lebih dikenal dengan Over Current Relay (OCR) merupakan peralatan yang mensinyalir adanya arus lebih, baik yang disebabkan oleh adanya gangguan hubung singkat atau overload yang dapat merusak peralatan sistem tenaga yang berada dalam wilayah proteksinya. Relai Arus Lebih ini digunakan hampir pada seluruh pola pengamanan sistem tenaga listrik, dan relai ini dapat digunakan sebagai pengaman utama ataupun pengaman cadangan [5].

\section{Relai Gangguan Tanah}

Relai Gangguan Ke Tanah atau Ground Faulth Relay (GFR) pada dasarnya mempunyai prinsip kerja yang sama dengan relai arus lebih OCR (Over Current Relay) namun memiliki perbedaan dalam kegunaannya. Bila Relai Arus Lebih mendeteksi adanya hubung singkat antar fasa, maka Relai Gangguan Ke Tanah mendeteksi adanya hubung singkat ke tanah [5].

\section{METODE PENELITIAN}

Sebelum menentukan arus hubung singkat, maka harus ditentukan terlebih dahulu rel daya tegangan primer di gardu induk untuk berbagai jenis gangguan, kemudian menentukan pada titik-titik lainnya yang letaknya semakin jauh dari gardu induk tersebut. Untuk menentukan arus gangguan hubung singkat, pertama-tama harus ditentukan terlebih dahulu besar impedansi sumber, kedua menentukan impedansi transformator tenaga, ketiga menentukan impedansi impedansi penyulang.

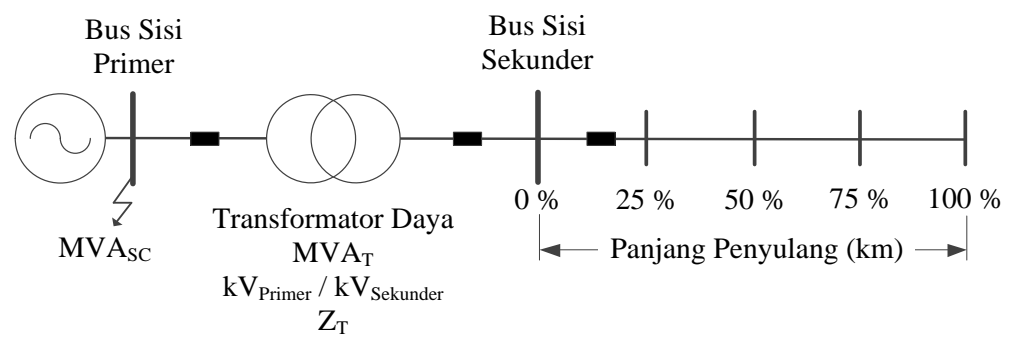

Gambar 1. Representasi Penyulang 


\section{Menentukan Impedansi Sumber}

Untuk menentukan impedansi sumber di bus sisi sekunder, maka harus ditentukan terlebih dahulu impedansi sumber di bus sisi primer. Impedansi sumber di bus sisi primer $\left(Z_{S}\right.$ (sisi primer $)$ ) dapat ditentukan dengan menggunakan persamaan sebagai berikut [1]:

$$
\left.Z_{S}(\text { sisi primer })=j X_{S} \text { (sisi primer }\right)=j \frac{k V^{2}(\text { sisi primer })}{M V A_{S C}}(\Omega)
$$

Arus gangguan hubung singkat yang akan dihitung adalah gangguan hubung singkat di sisi sekunder, maka impedansi tersebut harus dikonversikan dulu ke sisi sekunder. Untuk mengkonversikan impedansi yang terletak di sisi primer ke sisi sekunder, dapat ditentukan dengan menggunakan persamaan sebagai berikut [1]:

$$
Z_{S}(\text { sisi sekunder })=j X_{S}(\text { sisi sekunder })=\frac{k V^{2}(\text { sisi sekunder })}{k V^{2}(\text { sisi primer })} \times j X_{S}(\text { sisi primer })(\Omega)
$$

\section{Menentukan Impedansi Transformator}

Untuk menentukan impedansi suatu transformator yang diambil adalah harga reaktansinya, sedangkan tahanannya diabaikan karena harganya kecil. Maka impedansi transformator adalah [6]:

1. Menentukan nilai impedansi transformator pada $100 \%$ atau $Z_{T}(100 \%)=j X_{T}(100 \%)$ untuk transformator pada sisi sekunder, dengan menggunakan persamaan sebagai berikut:

$$
Z_{T}(100 \%)=j X_{T}(100 \%)=j \frac{\left.k V^{2} \text { (sisi sekunder }\right)}{M V A_{T}}(\Omega)
$$

2. Nilai impedansi transformator urutan positif $\left(Z_{1 T}=j X_{1 T}\right)$ sama dengan nilai impedansi transformator urutan negatif $\left(Z_{2 T}=j X_{2 T}\right)$, yaitu:

$$
Z_{1 T}=Z_{2 T}=j X_{1 T}=j X_{2 T}=Z_{T}(\%) \times j X_{T}(100 \%)(\Omega)
$$

3. Untuk transformator dengan hubungan belitan $Y Y$ dan tidak mempunyai belitan delta $(\Delta)$ di dalamnya, maka untuk menghitung besarnya impedansi transformator urutan nol $Z_{0 T}=j X_{0 T}$ berkisar antara $9 \mathrm{~s} / \mathrm{d} 14 \times j X_{1 T}$. Dalam penelitian ini diambil nilai sebesar:

$$
Z_{0 T}=j X_{0 T}=10 \times j X_{1 T}(\Omega)
$$

\section{Menentukan Impedansi Penyulang}

Nilai impedansi penyulang tergantung dari besarnya impedansi/km $\left(Z_{P}=R_{P}+j X_{P}\right)$ dan panjang penyulang $\left(l_{P}\right)$. Maka nilai impedansi penyulang adalah sebagai berikut [2]:

1. Impedansi penyulang urutan positif $\left(Z_{1 P}\right)$ sama dengan impedansi penyulang urutan negatif $\left(Z_{2 P}\right)$

$$
Z_{1 P}=Z_{2 P}=Z_{1 P} \times l_{P}=\left(R_{1 P}+j X_{1 P}\right) \times l_{P}(\Omega)
$$

2. Impedansi penyulang urutan nol $\left(Z_{0 P}\right)$

$$
Z_{0 P}=Z_{0 P} \times l_{P}=\left(R_{0 P}+j X_{0 P}\right) \times l_{P}(\Omega)
$$

Dari gambar 1 , apabila diasumsikan titik atau lokasi gangguan hubung singkat terjadi pada jarak $0 \%, 25 \%, 50 \%, 75 \%, 100 \%$ dari panjang penyulang, maka nilai impedansi penyulang dapat ditentukan dengan menggunakan persamaan sebagai berikut [4]:

\section{Tabel 1. Impedansi Penyulang Berdasarkan Lokasi Gangguan}

\begin{tabular}{|c|l|c|}
\hline $\begin{array}{c}\text { Panjang } \\
\text { Penyulang }(\%)\end{array}$ & $\begin{array}{c}\text { Impedansi Penyulang Urutan Positif dan } \\
\text { Urutan Negatif }\left(\boldsymbol{Z}_{\mathbf{1 P}}=\boldsymbol{Z}_{\mathbf{2 P}}\right)(\boldsymbol{\Omega})\end{array}$ & $\begin{array}{c}\text { Impedansi Penyulang Urutan Nol }\left(\boldsymbol{Z}_{\mathbf{0} \boldsymbol{P}}\right) \\
(\boldsymbol{\Omega})\end{array}$ \\
\hline $0 \%$ & $Z_{1 P}(0 \%)=Z_{2 P}(0 \%)=0 \% \times Z_{1 P}$ & $Z_{0 P}(0 \%)=0 \% \times Z_{0 P}$ \\
\hline $25 \%$ & $Z_{1 P}(25 \%)=Z_{2 P}(25 \%)=25 \% \times Z_{1 P}$ & $Z_{0 P}(25 \%)=25 \% \times Z_{0 P}$ \\
\hline $50 \%$ & $Z_{1 P}(50 \%)=Z_{2 P}(50 \%)=50 \% \times Z_{1 P}$ & $Z_{0 P}(50 \%)=50 \% \times Z_{0 P}$ \\
\hline $75 \%$ & $Z_{1 P}(75 \%)=Z_{2 P}(75 \%)=75 \% \times Z_{1 P}$ & $Z_{0 P}(75 \%)=75 \% \times Z_{0 P}$ \\
\hline $100 \%$ & $Z_{1 P}(100 \%)=Z_{2 P}(100 \%)=100 \% \times Z_{1 P}$ & $Z_{0 P}(100 \%)=100 \% \times Z_{0 P}$ \\
\hline
\end{tabular}




\section{Menentukan Impedansi Ekuivalen Jaringan}

Perhitungan yang akan dilakukan di sini adalah perhitungan besarnya nilai impedansi ekuivalen positif, negatif dan nol dari titik gangguan sampai ke sumber. Karena dari sejak sumber ke titik gangguan impedansi yang terbentuk adalah tersambung seri maka perhitungan $Z_{1 \text { eq }}$ dan $Z_{2 \text { eq }}$ dapat langsung dengan cara menjumlahkan impedansi tersebut, sedangkan untuk perhitungan $Z_{0} e q$ dimulai dari titik gangguan sampai ke transformator tenaga yang netralnya ditanahkan. Impedansi ekuivalen jaringan dapat ditentukan hitung dengan menggunakan persamaan sebagai berikut [2]:

1. Impedansi ekuivalen urutan positif dan urutan negatif $\left(Z_{1 \text { eq }}=Z_{2 \text { eq }}\right)$

$$
\begin{aligned}
& Z_{1 \text { eq }}=Z_{2 \text { eq }}=Z_{1 S}(\text { sisi sekunder })+Z_{1 T}+Z_{1 P} \\
& Z_{1 \text { eq }}=Z_{2 \text { eq }}=j X_{1 S}(\text { sisi sekunder })+j X_{1 T}+\left(R_{1 P}+j X_{1 P}\right)
\end{aligned}
$$

2. Impedansi ekuivalen urutan nol $\left(Z_{0}\right.$ eq $)$

$$
Z_{0 \text { eq }}=Z_{0 T}+3 R_{n}+Z_{0 P}=j X_{0 T}+3 R_{n}+\left(R_{0 P}+j X_{0 P}\right)
$$

Dari gambar 1 , apabila diasumsikan titik atau lokasi gangguan hubung singkat terjadi pada jarak $0 \%, 25 \%, 50 \%, 75 \%, 100 \%$ dari panjang penyulang, maka nilai impedansi ekuivalen jaringan dapat ditentukan dengan menggunakan persamaan sebagai berikut [4]:

Tabel 2. Impedansi Ekuivalen Jaringan Berdasarkan Lokasi Gangguan

\begin{tabular}{|c|l|l|}
\hline $\begin{array}{c}\text { Panjang } \\
\text { Penyulang } \\
(\boldsymbol{\%})\end{array}$ & $\begin{array}{c}\text { Impedansi Ekuivalen Jaringan Urutan Positif dan } \\
\text { Urutan Negatif }\left(\boldsymbol{Z}_{\mathbf{1} \text { eq }}=\boldsymbol{Z}_{\mathbf{2} \text { eq }}\right)(\boldsymbol{\Omega})\end{array}$ & $\begin{array}{c}\text { Impedansi Penyulang Urutan Nol }\left(\boldsymbol{Z}_{\mathbf{0 P}}\right) \\
(\boldsymbol{\Omega})\end{array}$ \\
\hline $0 \%$ & $Z_{1 \text { eq }}(0 \%)=Z_{2 \text { eq }}(0 \%)=j X_{1 S}+j X_{1 T}+Z_{1 P}(0 \%)$ & $Z_{0 \text { eq }}(0 \%)=j X_{0 T}+3 R_{n}+Z_{0 P}(0 \%)$ \\
\hline $25 \%$ & $Z_{1 e q}(25 \%)=Z_{2 \text { eq }}(0 \%)=j X_{1 S}+j X_{1 T}+Z_{1 P}(25 \%)$ & $Z_{0 \text { eq }}(25 \%)=j X_{0 T}+3 R_{n}+Z_{0 P}(25 \%)$ \\
\hline $50 \%$ & $Z_{1 e q}(50 \%)=Z_{2 e q}(0 \%)=j X_{1 S}+j X_{1 T}+Z_{1 P}(50 \%)$ & $Z_{0 e q}(50 \%)=j X_{0 T}+3 R_{n}+Z_{0 P}(50 \%)$ \\
\hline $75 \%$ & $Z_{1 e q}(75 \%)=Z_{2 e q}(75 \%)=j X_{1 S}+j X_{1 T}+Z_{1 P}(75 \%)$ & $Z_{0 \text { eq }}(75 \%)=j X_{0 T}+3 R_{n}+Z_{0 P}(75 \%)$ \\
\hline $100 \%$ & $Z_{1 e q}(100 \%)=Z_{2 e q}(100 \%)=j X_{1 S}+j X_{1 T}+Z_{1 P}(100 \%)$ & $Z_{0 \text { eq }}(100 \%)=j X_{0 T}+3 R_{n}+Z_{0 P}(100 \%)$ \\
\hline
\end{tabular}

\section{Menentukan Arus Gangguan Hubung Singkat}

Perhitungan arus gangguan hubung singkat dapat dihitung dengan menggunakan rumus dasar, impedansi ekivalen mana yang dimasukkan ke dalam rumus dasar tersebut adalah jenis gangguan hubung singkat tiga fasa, dua fasa, atau satu fasa ke tanah. Sehingga formula yang digunakan untuk perhitungan arus hubung singkat tiga fasa, dua fasa, dan satu fasa ke tanah berbeda.

1. Arus Gangguan Hubung Singkat 3 Fase

Arus gangguan hubung singkat 3 fase $\left(I_{h s 3}\right.$ fase $)$ dapat ditentukan dengan menggunakan persamaan sebagai berikut [2]:

$$
I_{h s 3 \text { fase }}=\frac{V_{L-N}}{Z_{1 e q}}=\frac{\frac{V_{L-L}}{\sqrt{3}}}{Z_{1 e q}}
$$

2. Arus Gangguan Hubung Singkat 2 Fase

Arus gangguan hubung singkat 2 fase ( $\left.I_{\text {hs } 2 \text { fase }}\right)$ dapat ditentukan dengan menggunakan persamaan sebagai berikut [2]:

$$
I_{h s 2 \text { fase }}=\frac{V_{L-L}}{Z_{1 \text { eq }}+Z_{2} e q}=\frac{V_{L-L}}{2 \times Z_{1 e q}}
$$

3. Arus Gangguan Hubung Singkat 1 Fase Ke Tanah

Arus gangguan hubung singkat 1 fase ke tanah ( $I_{h s} 1$ fasa ke tanah $)$ dapat ditentukan dengan menggunakan persamaan sebagai berikut [2]:

$$
I_{h s 1 \text { fasa ke tanah }}=\frac{3 \times V_{L-N}}{Z_{1 e q}+Z_{2} e q+Z_{0} e q}=\frac{3 \times \frac{V_{L-L}}{\sqrt{3}}}{2 \times Z_{1 e q}+Z_{0} e q}
$$


Dari gambar 1, apabila diasumsikan titik atau lokasi gangguan hubung singkat terjadi pada jarak $0 \%, 25 \%, 50 \%, 75 \%, 100 \%$ dari panjang penyulang, maka arus gangguan hubung singkat dapat ditentukan dengan menggunakan persamaan sebagai berikut [4]:

Tabel 3. Arus Gangguan Hubung Singkat Berdasarkan Lokasi Gangguan

\begin{tabular}{|c|c|c|c|}
\hline \multirow{3}{*}{$\begin{array}{c}\begin{array}{c}\text { Lokasi } \\
\text { Gangguan } \\
(\%)\end{array} \\
0 \%\end{array}$} & \multicolumn{3}{|c|}{ Arus Gangguan Hubung Singkat (A) } \\
\hline & 3 fase $\left(I_{h s} 3\right.$ fase $)$ & 2 fase $\left(I_{h s} 2\right.$ fase $)$ & 1 fase ke tanah ( $\left.I_{h s 1 \text { fasa ke tanah }}\right)$ \\
\hline & $I_{\text {hs } 3 \text { fase }}(0 \%)=\frac{V_{L-N}}{Z_{1 \text { eq }}(0 \%)}$ & $I_{\text {hs } 2 \text { fase }}(0 \%)=\frac{V_{L-L}}{2 \times Z_{1 \text { eq }}(0 \%)}$ & $I_{h s 1 \text { fasa ke tanah }}(0 \%)=\frac{3 \times \frac{V_{L-L}}{\sqrt{3}}}{2 \times Z_{1 e q}(0 \%)+Z_{0 \text { eq }}(0 \%)}$ \\
\hline $25 \%$ & $I_{h s 3 \text { fase }}(25 \%)=\frac{V_{L-N}}{Z_{1 e q}(25 \%)}$ & $I_{\text {hs } 2 \text { fase }}(25 \%)=\frac{V_{L-N}}{2 \times Z_{1 e q}(25 \%)}$ & $\begin{array}{l}I_{\text {hs } 1 \text { fasa ke tanah }}(25 \%)= \\
\frac{3 \times \frac{V_{L-L}}{\sqrt{3}}}{2 \times Z_{1 e q}(25 \%)+Z_{0} e q}(25 \%)\end{array}$ \\
\hline $50 \%$ & $I_{\text {hs } 3 \text { fase }}(50 \%)=\frac{V_{L-N}}{Z_{1 \text { eq }}(50 \%)}$ & $I_{h s ~ 2 ~ f a s e}(50 \%)=\frac{V_{L-N}}{2 \times Z_{1 e q}(50 \%)}$ & $\begin{array}{l}I_{\text {hs } 1 \text { fasa ke tanah }}(50 \%)= \\
\frac{3 \times \frac{V_{L-L}}{\sqrt{3}}}{2 \times Z_{1 e q}(50 \%)+Z_{0 e q}(50 \%)}\end{array}$ \\
\hline $75 \%$ & $I_{\text {hs } 3 \text { fase }}(75 \%)=\frac{V_{L-N}}{Z_{1 \text { eq }}(75 \%)}$ & $I_{\text {hs } 2 \text { fase }}(75 \%)=\frac{V_{L-N}}{2 \times Z_{1 e q}(75 \%)}$ & $\begin{array}{l}I_{\text {hs } 1 \text { fasa ke tanah }}(75 \%)= \\
\frac{3 \times \frac{V_{L-L}}{\sqrt{3}}}{2 \times Z_{1 e q}(75 \%)+Z_{0 e q}(75 \%)}\end{array}$ \\
\hline $100 \%$ & $\begin{array}{l}I_{h s 3 \text { fase }}(100 \%)= \\
\frac{V_{L-N}}{Z_{1 e q}(100 \%)}\end{array}$ & $\begin{array}{l}I_{\text {hs } 2 \text { fase }}(100 \%)= \\
\frac{V_{L-N}}{2 \times Z_{1 \text { eq }}(100 \%)}\end{array}$ & $\begin{array}{l}I_{\text {hs } 1 \text { fasa } k e \operatorname{tanah}}(100 \%)= \\
\frac{3 \times \frac{V_{L-L}}{\sqrt{3}}}{2 \times Z_{1 e q}(100 \%)+Z_{0 e q}(100 \%)}\end{array}$ \\
\hline
\end{tabular}

\section{Menentukan Setting Relai Arus Lebih Di Sisi Penyulang 20 kV}

\section{Setting Arus}

Untuk setting relai yang terpasang di penyulang dihitung berdasarkan arus beban maksimum. Untuk relai inverse biasa diset sebesar 1,05 sampai dengan 1,1 x $\mathrm{I}_{\text {maks }}$, sedangkan untuk relai definite diset sebesar 1,2 sampai dengan 1,3 $\mathrm{x} \mathrm{I}_{\text {maks }}$. Persyaratan lain yang harus dipenuhi yaitu untuk penyetelan waktu minimum dari relai arus lebih (terutama di penyulang tidak lebih kecil dari 0,3 detik). Keputusan ini diambil agar relai tidak sampai trip lagi akibat adanya arus inrush dari transformator-transformator distribusi yang sudah tersambung di jaringan distribusi, pada saat PMT penyulang tersebut di masukan. Setting arus pada sisi primer transformator adalah [1]:

$$
I_{\text {set }}(\text { primer })=1,05 \times I_{\text {beban }}
$$

Nilai arus tersebut merupakan nilai setting pada sisi primer, sedangkan nilai yang akan disetkan pada relai adalah nilai sekundernya. Oleh karena itu dihitung menggunakan nilai rasio transformator arus yang terpasang pada penyulang. Besarnya arus pada sisi sekunder adalah [1]:

$$
I_{\text {set }}(\text { sekunder })=I_{\text {set }}(\text { primer }) \times \frac{1}{\text { Ratio CT }}
$$

2. Setting Waktu

Arus gangguan yang dipilih untuk menentukan besarnya setting TMS relay OCR sisi penyulang $20 \mathrm{kV}$ transformator tenaga yaitu arus gangguan hubung singkat tiga fasa di $0 \%$ panjang penyulang. Waktu kerja paling hilir yang ditetapkan $t=0,3$ sekon Keputusan ini diambil agar relai tidak sampai trip lagi akibat adanya arus inrush dari transformator-transformator distribusi yang sudah tersambung di jaringan distribusi, pada saat PMT penyulang tersebut dimasukan. Maka setting waktu (TMS) adalah sebagai berikut [1]:

$$
T M S=\frac{t \times\left(\left(\frac{I_{\text {fault }}}{I_{\text {set }}}\right)^{0,02}-1\right)}{0,14}=\frac{t \times\left(\left(\frac{I_{3} \text { fase }(0 \%)}{I_{\text {set }}(\text { primer })}\right)^{0,02}-1\right)}{0,14}
$$

\section{Menentukan Setting Relai Arus Lebih Di Sisi Incoming 20 kV}

\section{Setting Arus}


Berbeda dengan sisi penyulang, pada sisi incoming $20 \mathrm{kV}$ diperlukan nilai arus nominal dalam menentukan setting relainya. Maka arus nominal transformator pada sisi $20 \mathrm{kV}$ adalah [1]:

$$
I_{\text {nominal }}(20 \mathrm{kV})=\frac{k V A_{T}}{\sqrt{3} V_{L-L}}
$$

Setting arus untuk Relai Arus Lebih, pada sisi primer adalah:

$$
I_{\text {set }}(\text { primer })=1,05 \times I_{\text {nominal }}(20 \mathrm{kV})
$$

Maka setting arus untuk Relai Arus Lebih, pada sisi sekunder adalah:

$$
I_{\text {set }}(\text { sekunder })=I_{\text {set }}(\text { primer }) \times \frac{1}{\text { Ratio CT }}
$$

2. Setting Waktu Kerja atau Time Multiplier Setting (TMS)

Arus gangguan yang dipilih untuk menentukan besarnya setting TMS relai arus lebih atau OCR sisi incoming $20 \mathrm{kV}$ transformator tenaga yaitu arus gangguan hubung singkat 3 fase di $0 \%$ panjang penyulang. Waktu kerja incoming didapat dengan waktu kerja relai disisi hilir $+0,4$ detik. Maka $t_{\text {incoming }}=(0,3+0,4)=0,7$ detik. Setelah diketahui nilai ketetapan $\mathrm{t}=0,7$ detik, maka nilai TMS dapat diketahui yaitu [1]:

$$
T M S=\frac{t \times\left(\left(\frac{I_{\text {fault }}}{I_{\text {set }}}\right)^{0,02}-1\right)}{0,14}=\frac{t \times\left(\left(\frac{I_{3} \text { fase }(0 \%)}{I_{\text {set }}(\text { primer })}\right)^{0,02}-1\right)}{0,14}
$$

\section{Menentukan Setting Relai Gangguan Ke Tanah Di Sisi Penyulang 20 kV}

\section{Setting Arus}

Untuk setting arus di penyulang menggunakan pedoman yaitu setting arus gangguan ke tanah di penyulang diset $10 \% \mathrm{x}$ arus gangguan 1 fase ke tanah terkecil di penyulang tersebut. Hal ini dilakukan untuk menampung tahanan busur. Dimana arus gangguan terkecil terletak di lokasi gangguan 100\% maka setting arus untuk Relai Gangguan Ke Tanah, pada sisi primer adalah [1]:

$$
I_{\text {set }}(\text { primer })=10 \% \times I_{1 \text { fasa ke tanah }}(100 \%)
$$

Maka setting arus untuk Relai Gangguan Ke Tanah, pada sisi sekunder adalah:

$$
I_{\text {set }}(\text { sekunder })=I_{\text {set }}(\text { primer }) \times \frac{1}{\text { Ratio } C T}
$$

2. Setting Waktu Kerja atau Time Multiplier Setting (TMS)

Arus gangguan yang dipilih untuk menentukan besarnya setting TMS Relai Gangguan Ke Tanah atau Ground Fault Relay (GFR) sisi penyulang $20 \mathrm{kV}$ transformator tenaga yaitu arus gangguan hubung singkat 1 fase di $0 \%$ panjang penyulang. Waktu kerja paling hilir yang ditetapkan $t=0,3$ sekon, maka nilai TMS dapat diketahui yaitu [1]:

$$
T M S=\frac{t \times\left(\left(\frac{I_{\text {fault }}}{I_{\text {set }}}\right)^{0,02}-1\right)}{0,14}=\frac{t \times\left(\left(\frac{I_{1 \text { fasa ketanah }}(0 \%)}{I_{\text {set }}(\text { primer })}\right)^{0,02}-1\right)}{0,14}
$$

\section{Menentukan Setting Relai Gangguan Ke Tanah Di Sisi Incoming 20 kV}

\section{Setting Arus}

Agar Relai Gangguan Ke Tanah sisi incoming lebih peka atau cepat merasakan gangguan sesuai dengan sifatnya sebagai backup setelah relai sisi penyulang maka dalam menentukan settingnya dibuat lebih kecil yaitu $8 \%$ x arus gangguan 1 fase ke tanah terkecil yaitu pada lokasi $100 \%$. Maka setting arus untuk Relai Gangguan Ke Tanah, pada sisi primer adalah:

$$
I_{\text {set }}(\text { primer })=8 \% \times I_{1 \text { fasa } \text { ke tanah }}(100 \%)
$$

Maka setting arus untuk relai gangguan tanah, pada sisi sekunder adalah:

$$
I_{\text {set }}(\text { sekunder })=I_{\text {set }}(\text { primer }) \times \frac{1}{\text { Ratio CT }}
$$

2. Setting Waktu Kerja atau Time Multiplier Setting (TMS) 
Arus gangguan yang dipilih untuk menentukan besarnya setting TMS Relai Gangguan Ke Tanah atau GFR sisi incoming $20 \mathrm{kV}$ transformator tenaga yaitu arus gangguan hubung singkat 3 fase di $0 \%$ panjang penyulang. Waktu kerja incoming didapat dengan waktu kerja relai disisi hilir $+0,4$ detik. Maka $t_{\text {incoming }}=(0,3+0,4)=0,7$ detik. Setelah diketahui nilai ketetapan $t=0,7$ detik, maka nilai TMS dapat diketahui yaitu:

$$
T M S=\frac{t \times\left(\left(\frac{I_{\text {fault }}}{I_{\text {set }}}\right)^{0,02}-1\right)}{0,14}=\frac{t \times\left(\left(\frac{I_{1} \text { fasa ketanah }(0 \%)}{I_{\text {set }}(\text { primer })}\right)^{0,02}-1\right)}{0,14}
$$

\section{HASIL DAN PEMBAHASAN}

Gardu Induk Bungaran Palembang mempunyai fungsi menyalurkan energi listrik ke konsumen melalui jaringan distribusi tegangan menengah. Untuk melayani kebutuhan energi listrik konsumen, saat ini Transformator 1, 30 MVA 70/20 kV Gardu Induk Bungaran Palembang terdapat Penyulang Cendana. Energi listrik yang disalurkan melalui pada jaringan distribusi tegangan menengah ke konsumen harus mempunyai mutu dan keandalan yang tinggi. Akan tetapi bagaimanapun baiknya suatu sistem, gangguan tidak bisa sama sekali dihindarkan. Gangguan pada umumnya berupa gangguan hubung singkat antar fase atau fase dengan tanah. Gangguan hubung singkat semacam ini dapat menimbulkan arus yang besar dan dapat merusak peralatan listrik.

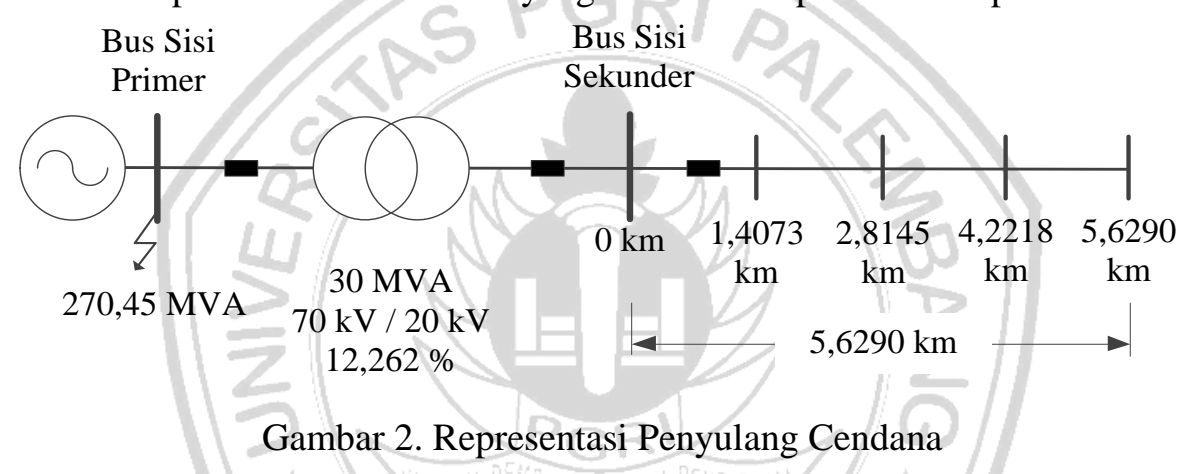

\section{Data Transformator}

Data Transformator 1, 30 MVA 70/20 kV di PT PLN (Persero) Gardu Induk Bungaran Palembang adalah sebagai berikut:

- $\quad$ Merk

Schneider

- $\quad$ Type

Micom P141

- $\quad$ Nominal Ratting MVA $\left(M V A_{T}\right)$

- $\quad$ Frequency Hertz

: $30 \mathrm{MVA}$

- $\quad$ Tegangan Primer (kVsisi primer)

: $50 \mathrm{~Hz}$

- $\quad$ Tegangan Sekunder (kVsisi sekunder)

- Arus Primer (Inominal primer)

: $70 \mathrm{kV}$

- $\quad$ Arus Sekunder ( $I_{\text {nominal }}$ sekunder $)$

: $20 \mathrm{kV}$

- Phasa

: $247,4358 \mathrm{~A}$

- Phasa

- $\quad$ Impedance $\left(Z_{T} \%\right)$

- Vector Group

- Tahanan Pentanahan $\left(R_{n}\right)$

: $866,0254 \mathrm{~A}$

: 3 Phasa

: $12,262 \%$

: YNyn0

: $40 \Omega$

\section{Data Penyulang}

Data Penyulang Cendana pada Transformator 1, 30 MVA 70/20 kV di PT PLN (Persero) Gardu Induk Bungaran Palembang adalah sebagai berikut: 
- Jenis Pengantar

- Panjang $\left(l_{P}\right)$

- Impedansi Urutan Positif $\left(Z_{1 P}\right) \quad: \quad 0,2162+\mathrm{j} 0,3305 \Omega / \mathrm{km}$

- $\quad$ Impedansi Urutan Negatif $\left(Z_{2 P}\right)$ : $0,2162+\mathrm{j} 0,3305 \Omega / \mathrm{km}$

- $\quad$ Impedansi Urutan $\operatorname{Nol}\left(Z_{0 P}\right) \quad: \quad 0,3631+\mathrm{j} 1,6180 \Omega / \mathrm{km}$

\section{Perhitungan Impedansi Sumber}

Daya hubung singkat di bus sisi primer $(70 \mathrm{kV})$ pada Gardu Induk adalah $M V A_{S C}=$ 270,45 MVA. Impedansi sumber di sisi primer $Z_{S}(70 \mathrm{kV})$ dapat ditentukan dengan persamaan (1):

$$
Z_{S}(70 \mathrm{kV})=j X_{S}(70 \mathrm{kV})=j \frac{k V^{2}(70 \mathrm{kV})}{M V A_{S C}}=j \frac{70^{2}}{270,45}=j 18,1180 \Omega
$$

Kemudian impedansi sumber di sisi sekunder $Z_{S}(20 \mathrm{kV})$ dapat ditentukan dengan persamaan (2):

$$
Z_{S}(20 \mathrm{kV})=j X_{S}(20 \mathrm{kV})=\frac{k V^{2}(20 \mathrm{kV})}{k V^{2}(70 \mathrm{kV})} \times j X_{S}(70 \mathrm{kV})=\frac{20^{2}}{70^{2}} \times j 18,1180=j 1,4790 \Omega
$$

\section{Perhitungan Impedansi Transformator}

Impedansi transformator pada $100 \%$ atau $Z_{T}(100 \%)=j X_{T}(100 \%)$ untuk transformator pada sisi sekunder, dapat ditentukan dengan menggunakan persamaan (3) sebagai berikut:

$$
Z_{T}(100 \%)=j X_{T}(100 \%)=j \frac{k V^{2}(20 k V)}{M V A_{T}}=j \frac{20^{2}}{30}=j 13,3333 \Omega
$$

Maka nilai impedansi transformator urutan positif dan nilai impedansi transformator urutan negatif $\left(Z_{1 T}=Z_{2 T}\right)$ dapat ditentukan dengan menggunakan persamaan (4):

$$
Z_{1 T}=Z_{2 T}=j X_{1 T}=j X_{2 T}=Z_{T}(\%) \times j X_{T}(100 \%)=0,12262 \times j 13,3333=j 1,6349 \Omega
$$

Kemudian impedansi transformator urutan nol $Z_{0 T}=j X_{0 T}$ dapat ditentukan dengan menggunakan persamaan (5) sebagai berikut:

$$
Z_{0 T}=j X_{0 T}=10 \times j X_{1 T}=10 \times j 1,6349=16,3493 \Omega
$$

\section{Perhitungan Impedansi Penyulang}

Penyulang Cendana menggunakan jenis penghantar AAAC $150 \mathrm{~mm}^{2}$ dengan panjang jaringan $5,6290 \mathrm{~km}$. Maka nilai impedansi penyulang urutan positif $\left(Z_{1 P}\right)$ dan impedansi penyulang urutan negatif $\left(Z_{2 P}\right)$ dapat ditentukan dengan menggunakan persamaan (6) sebagai berikut:

$$
Z_{1 P}=Z_{2 P}=\left(R_{1 P}+j X_{1 P}\right) \times l_{P}=(0,2162+j 0,3305) \times 5,6290=1,2170+j 1,8604 \Omega
$$

Kemudian nilai impedansi penyulang urutan nol $\left(Z_{0 P}\right)$ dapat ditentukan dengan menggunakan persamaan (7) sebagai berikut:

\begin{tabular}{|c|c|c|c|}
\hline \multicolumn{2}{|c|}{ Panjang Penyulang } & \multirow{2}{*}{$Z_{1 P}=Z_{2 P}(\Omega)$} & \multirow{2}{*}{$Z_{0 P}(\Omega)$} \\
\hline$(\%)$ & $(\mathbf{k m})$ & & \\
\hline $0 \%$ & 0,0000 & $0,0000+j 0,0000=0,0000 \angle 0,0000^{\circ}$ & $0,0000+j 0,0000=0,0000 \angle 0,0000^{\circ}$ \\
\hline $25 \%$ & 1,4073 & $0,3042+j 0,4651=0,5558 \angle 56,8089^{\circ}$ & $0,5110+j 2,2769=2,3336 \angle 77,3516^{\circ}$ \\
\hline $50 \%$ & 2,8145 & $0,6085+j 0,9302=1,1115 \angle 56,8089^{\circ}$ & $1,0219+j 4,5539=4,6671 \angle 77,3516^{\circ}$ \\
\hline $75 \%$ & 4,2218 & $0,9127+j 1,3953=1,6673 \angle 56,8089^{\circ}$ & $1,5329+j 6,8308=7,0007 \angle 77,3516^{\circ}$ \\
\hline $100 \%$ & 5,6290 & $1,2170+j 1,8604=2,2231 \angle 56,8089^{\circ}$ & $2,0439+j 9,1077=9,3342 \angle 77,3516^{\circ}$ \\
\hline
\end{tabular}

$$
Z_{0 P}=\left(R_{0 P}+j X_{0 P}\right) \times l_{P}=(0,3631+j 1,6180) \times 5,6290=2,0439+j 9,1077 \Omega
$$

Dengan demikian nilai impedansi penyulang urutan positif dan urutan negatif $\left(Z_{1 P}=Z_{2 P}\right)$ serta impedansi penyulang urutan nol $\left(Z_{0 P}\right)$ untuk lokasi gangguan dengan jarak $0 \%, 25 \%, 50 \%, 75 \%$ dan $100 \%$ dari panjang penyulang, adalah:

Tabel 4. Hasil Perhitungan Impedansi Penyulang Berdasarkan Lokasi Gangguan

Sumber: Hasil Perhitungan 


\section{Perhitungan Impedansi Ekuivalen Jaringan}

Impedansi ekuivalen jaringan urutan positif dan urutan negatif $\left(Z_{1 \text { eq }}=Z_{2 \text { eq }}\right)$ dapat ditentukan dengan menggunakan persamaan (8) sebagai berikut:

$$
\begin{aligned}
& Z_{1 \text { eq }}=Z_{2 \text { eq }}=j X_{1 S}(20 \mathrm{kV})+j X_{1 T}+\left(R_{1 P}+j X_{1 P}\right) \\
& Z_{1 \text { eq }}=Z_{2 \text { eq }}=j 1,4790+j 1,6349+(1,2170+j 1,8604)=1,2170+j 4,9743 \Omega
\end{aligned}
$$

Kemudian impedansi ekuivalen jaringan urutan nol $\left(Z_{0 \text { eq }}\right)$ dapat ditentukan dengan menggunakan persamaan (9) sebagai berikut:

$$
\begin{aligned}
& Z_{0 \text { eq }}=j X_{0 T}+3 R_{n}+\left(R_{0 P}+j X_{0 P}\right) \\
& Z_{0 \text { eq }}=j 16,3493+j 120,0000+(2,0439+j 9,1077)=122,0439+j 25,4571 \Omega
\end{aligned}
$$

Dengan demikian nilai impedansi ekuivalen penyulang urutan positif dan urutan negatif $\left(Z_{1 \text { eq }}=\right.$

\begin{tabular}{|c|c|c|c|}
\hline \multicolumn{2}{|c|}{ Panjang Penyulang } & \multirow{2}{*}{$Z_{1 e q}=Z_{2 e q}(\Omega)$} & \multirow{2}{*}{$Z_{0 e q}(\Omega)$} \\
\hline$(\%)$ & $(\mathbf{k m})$ & & \\
\hline $0 \%$ & 0,0000 & $0,0000+j 3,1139=3,1139 \angle 0,0000^{\circ}$ & $120,0000+j 16,3493=121,1086 \angle 7,7585^{\circ}$ \\
\hline $25 \%$ & 1,4073 & $0,3042+j 3,5790=3,5920 \angle 85,1411^{\circ}$ & $120,5110+j 18,6263=121,9419 \angle 8,7862^{\circ}$ \\
\hline $50 \%$ & 2,8145 & $0,6085+j 4,0441=4,0897 \angle 81,4433^{\circ}$ & $121,0219+j 20,9032=122,8139 \angle 9,7996^{\circ}$ \\
\hline $75 \%$ & 4,2218 & $0,9127+j 4,5092=4,6007 \angle 78,5570^{\circ}$ & $121,5329+j 23,1801=123,7238 \angle 10,7984^{\circ}$ \\
\hline $100 \%$ & 5,6290 & $1,2170+j 4,9743=5,1210 \angle 76,2524^{\circ}$ & $122,0439+j 25,4571=124,6707 \angle 11,7823^{\circ}$ \\
\hline
\end{tabular}
$\left.Z_{2 \text { eq }}\right)$ serta impedansi ekuivalen penyulang urutan nol $\left(Z_{0}\right.$ eq $)$ untuk lokasi gangguan dengan jarak 0 $\%, 25 \%, 50 \%, 75 \%$ dan $100 \%$ dari panjang penyulang, adalah:

Tabel 5. Hasil Perhitungan Impedansi Ekuivalen Berdasarkan Lokasi Gangguan

Sumber: Hasil Perhitungan

\section{Perhitungan Arus Gangguan Hubung Singkat}

1. Arus Gangguan Hubung Singkat 3 Fase

Arus gangguan hubung singkat 3 fase $\left(I_{3}\right.$ fase $)$ dapat ditentukan dengan menggunakan persamaan (10) sebagai berikut:

$$
I_{\text {hs } 3 \text { fase }}=\frac{\frac{V_{L-L}}{\sqrt{3}}}{Z_{1 \text { eq }}}=\frac{\frac{20.000}{\sqrt{3}}}{5,1210 \angle 76,2524^{\circ}}=\frac{11.547,0054}{5,1210 \angle 76,2524^{\circ}}=2.254,8158 \angle-76,2524 \mathrm{~A}
$$

2. Arus Gangguan Hubung Singkat 2 Fase

Arus gangguan hubung singkat 2 fase $\left(I_{2}\right.$ fase $)$ dapat ditentukan dengan menggunakan persamaan (11) sebagai berikut:

$$
I_{\text {hs } 2 \text { fase }}=\frac{V_{L-L}}{2 \times Z_{1 e q}}=\frac{20.000}{2 \times\left(5,1210 \angle 76,2524^{\circ}\right)}=\frac{20.000}{10,2421 \angle 76,2524^{\circ}}=1.952,7278 \angle-76,2524 \mathrm{~A}
$$

3. Arus Gangguan Hubung Singkat 1 fase ke tanah

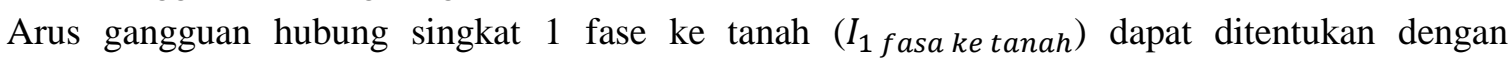
menggunakan persamaan (12) sebagai berikut:

$$
\begin{aligned}
I_{h s 1 \text { fasa ke tanah }} & =\frac{3 \times \frac{V_{L-L}}{\sqrt{3}}}{2 \times Z_{1} e q+Z_{0} e q}=\frac{3 \times \frac{20.000}{\sqrt{3}}}{2 \times(1,2170+j 4,9743)+122,0439+j 25,4571}=\frac{34.641,0162}{124,4779+j 35,4057} \\
I_{h s 1 \text { fasa ke tanah }} & =\frac{34.641,0162}{129,4152 \angle 15,8775^{\circ}}=267,6734 \angle-15,8775^{\circ} \mathrm{A}
\end{aligned}
$$

Dengan demikian nilai arus gangguan hubung singkat 3 fase $\left(I_{h s} 3\right.$ fase $), 2$ fase $\left(I_{h s} 2\right.$ fase $), 1$ fase ke tanah $\left(I_{\text {hs } 1 \text { fasa ke tanah }}\right)$ untuk lokasi gangguan dengan jarak $0 \%, 25 \%, 50 \%, 75 \%$ dan $100 \%$ dari panjang penyulang, adalah: 
Tabel 6. Hasil Perhitungan Arus Gangguan Hubung Singkat Berdasarkan Lokasi Gangguan

\begin{tabular}{|c|c|c|c|c|}
\hline \multicolumn{2}{|c|}{ Lokasi Gangguan } & \multirow{2}{*}{$I_{\text {hs } 3 \text { fase }}$ (A) } & \multirow{2}{*}{$I_{\text {hs } 2 \text { fase }}$ (A) } & \multirow{2}{*}{$I_{h s 1 \text { fasa ke tanah }}$ (A) } \\
\hline$(\%)$ & $(\mathbf{k m})$ & & & \\
\hline $0 \%$ & 0,0000 & $3.708,1540 \angle 0,0000^{\circ}$ & $3.211,3556 \angle 0,0000^{\circ}$ & $283,6976 \angle-10,6553^{\circ}$ \\
\hline $25 \%$ & 1,4073 & $3.214,6860 \angle-85,1411^{\circ}$ & $2.783,9997 \angle-85,1411^{\circ}$ & $279,7384 \angle-12,0179^{\circ}$ \\
\hline $50 \%$ & 2,8145 & $2.823,4607 \angle-81,4433^{\circ}$ & $2.445,1887 \angle-81,4433^{\circ}$ & $275,7387 \angle-13,3424^{\circ}$ \\
\hline $75 \%$ & 4,2218 & $2.509,8433 \angle-78,5570^{\circ}$ & $2.173,5881 \angle-78,5570^{\circ}$ & $271,7127 \angle-14,6288^{\circ}$ \\
\hline $100 \%$ & 5,6290 & $2.254,8158 \angle-76,2524^{\circ}$ & $1.952,7278 \angle-76,2524^{\circ}$ & $267,6734 \angle-15,8775^{\circ}$ \\
\hline
\end{tabular}

Sumber: Hasil Perhitungan

\section{Perhitungan Setting Relai Arus Lebih Di Sisi Penyulang 20 kV}

1. Setting Arus

$I_{\text {beban }}=285,9450 \mathrm{~A}$

Rasio $C T=300 / 5 \mathrm{~A}$

Setting arus untuk Relai Arus Lebih, pada sisi primer dapat ditentukan dengan menggunakan persamaan (13) sebagai berikut:

$$
I_{\text {set }}(\text { primer })=1,05 \times I_{\text {beban }}=1,05 \times 285,9450=300,2423 \mathrm{~A}
$$

Maka besarnya arus pada sisi sekunder dapat ditentukan dengan menggunakan persamaan (14) sebagai berikut:

$$
I_{\text {set }}(\text { sekunder })=I_{\text {set }}(\text { primer }) \times \frac{1}{\text { Ratio CT }}=300,2423 \times \frac{1}{300 / 5}=5,0040 \mathrm{~A}
$$

2. Setting Waktu

Setting waktu (TMS) dapat ditentukan dengan menggunakan persamaan (15) sebagai berikut:

$$
T M S=\frac{t \times\left(\left(\frac{I_{3} \text { fase }(0 \%)}{I_{\text {set }}(\text { primer })}\right)^{0,02}-1\right)}{0,14}=\frac{0,3 \times\left(\left(\frac{3708,1540}{300,2423}\right)^{0,02}-1\right)}{0,14}=0,1105
$$

\section{Perhitungan Setting Relai Arus Lebih Di Sisi Incoming 20 kV}

1. Setting Arus

Rasio CT $=1.000 / 5 \mathrm{~A}$

Arus nominal transformator pada sisi $20 \mathrm{kV}$ dapat ditentukan dengan menggunakan persamaan (16) sebagai berikut:

$$
I_{\text {nominal }}(20 \mathrm{kV})=\frac{k V A_{T}}{\sqrt{3} V_{L-L}}=\frac{30.000}{\sqrt{3} \times 20}=866,0254 \mathrm{~A}
$$

Setting arus untuk Relai Arus Lebih, pada sisi primer dapat ditentukan dengan menggunakan persamaan (17) sebagai berikut:

$$
I_{\text {set }}(\text { primer })=1,05 \times I_{\text {nominal }}(20 \mathrm{kV})=1,05 \times 866,0254=909,3267 \mathrm{~A}
$$

Maka setting arus untuk Relai Arus Lebih, pada sisi sekunder dapat ditentukan dengan menggunakan persamaan (18) sebagai berikut:

$$
I_{\text {set }}(\text { sekunder })=I_{\text {set }}(\text { primer }) \times \frac{1}{\text { Ratio CT }}=909,3267 \times \frac{1}{1.000 / 5}=4,5466 \mathrm{~A}
$$

2. Setting Waktu

Setting waktu (TMS) dapat ditentukan dengan menggunakan persamaan (19) sebagai berikut:

$$
T M S=\frac{t \times\left(\left(\frac{I_{3 \text { fase }}(0 \%)}{I_{\text {set }}(\text { primer })}\right)^{0,02}-1\right)}{0,14}=\frac{0,3 \times\left(\left(\frac{3708,1540}{300,2423}\right)^{0,02}-1\right)}{0,14}=0,1426 \mathrm{~A}
$$

\section{Menentukan Setting Relai Gangguan Ke Tanah Di Sisi Penyulang 20 kV}

1. Setting Arus 
Arus gangguan terkecil terletak di lokasi gangguan 100\% maka setting arus untuk relai Gangguan Ke Tanah dapat ditentukan dengan menggunakan persamaan (20) sebagai berikut:

$$
I_{\text {set }}(\text { primer })=10 \% \times I_{1 \text { fasa ke tanah }}(100 \%)=0,1 \times 267,6734=26,7673 \mathrm{~A}
$$

Maka setting arus untuk Relai Gangguan Ke Tanah, pada sisi sekunder dapat ditentukan dengan menggunakan persamaan (21) sebagai berikut:

$$
I_{\text {set }}(\text { sekunder })=I_{\text {set }}(\text { primer }) \times \frac{1}{\text { Ratio CT }}=26,7673 \times \frac{1}{300 / 5}=0,4461 \mathrm{~A}
$$

2. Setting Waktu

Setting waktu (TMS) dapat ditentukan dengan menggunakan persamaan (22) sebagai berikut:

$$
T M S=\frac{t \times\left(\left(\frac{I_{1} \text { fasa ke tanah }(0 \%)}{I_{\text {set }}(\text { primer })}\right)^{0,02}-1\right)}{0,14}=\frac{0,3 \times\left(\left(\frac{(283,6976}{26,7673}\right)^{0,02}-1\right)}{0,14}=0,1036
$$

\section{Perhitungan Setting Relai Gangguan Ke Tanah Di Sisi Incoming 20 kV}

\section{Setting Arus}

Setting arus untuk Relai Gangguan Ke Tanah pada sisi primer, dapat ditentukan dengan menggunakan persamaan (23) sebagai berikut:

$$
I_{\text {set }}(\text { primer })=8 \% \times I_{1 \text { fasa ke tanah }}(100 \%)=0,1 \times 267,6734=21,4139 \mathrm{~A}
$$

Maka setting arus untuk Relai Gangguan Ke Tanah, pada sisi sekunder dapat ditentukan dengan menggunakan persamaan (24) sebagai berikut:

$$
I_{\text {set }}(\text { sekunder })=I_{\text {set }}(\text { primer }) \times \frac{1}{\text { Ratio CT }}=21,4139 \times \frac{1}{1.000 / 5}=0,1071 \mathrm{~A}
$$

2. Setting Waktu

Setting waktu (TMS) dapat ditentukan dengan menggunakan persamaan (25) sebagai berikut:

$$
T M S=\frac{t \times\left(\left(\frac{I_{1} \text { fasa ke tanah }(0 \%)}{I_{\text {set }}(\text { primer })}\right)^{0,02}-1\right)}{0,14}=\frac{0,3 \times\left(\left(\frac{(283,6976}{21,4139}\right)^{0,02}-1\right)}{0,14}=0,1226
$$

Tabel 7. Hasil Perhitungan Waktu Kerja Relai Untuk Gangguan Hubung Singkat Berdasarkan Lokasi Gangguan

\begin{tabular}{|c|c|c|c|c|c|c|c|c|c|c|}
\hline \multicolumn{2}{|c|}{$\begin{array}{c}\text { Lokasi } \\
\text { Gangguan }\end{array}$} & \multicolumn{2}{|c|}{ Gangguan 3 Fase (detik) } & \multicolumn{2}{c|}{ Gangguan 2 Fase (detik) } & \multicolumn{3}{c|}{$\begin{array}{c}\text { Gangguan 1 Fase Ke Tanah } \\
\text { (detik) }\end{array}$} \\
\hline$(\boldsymbol{\%})$ & $\mathbf{( K m )}$ & $\begin{array}{c}\text { Relai } \\
\text { Incoming }\end{array}$ & $\begin{array}{c}\text { Relai } \\
\text { Penyulang }\end{array}$ & $\begin{array}{c}\text { Selisish } \\
\text { Waktu }\end{array}$ & $\begin{array}{c}\text { Relai } \\
\text { Incoming }\end{array}$ & $\begin{array}{c}\text { Relai } \\
\text { Penyulang }\end{array}$ & $\begin{array}{c}\text { Selisish } \\
\text { Waktu }\end{array}$ & $\begin{array}{c}\text { Relai } \\
\text { Incoming }\end{array}$ & $\begin{array}{c}\text { Relai } \\
\text { Penyulang }\end{array}$ & $\begin{array}{c}\text { Selisish } \\
\text { Waktu }\end{array}$ \\
\hline 0 & 0,0000 & 0,7000 & 0,3000 & 0,4000 & 0,7809 & 0,3187 & 0,4623 & 0,7000 & 0,3000 & 0,4000 \\
\hline 25 & 1,3768 & 0,7803 & 0,3185 & 0,4618 & 0,8819 & 0,3396 & 0,5423 & 0,7039 & 0,3018 & 0,4021 \\
\hline 50 & 2,7535 & 0,8708 & 0,3374 & 0,5334 & 0,9988 & 0,3611 & 0,6378 & 0,7080 & 0,3037 & 0,4043 \\
\hline 75 & 4,1303 & 0,9729 & 0,3565 & 0,6164 & 1,1351 & 0,3830 & 0,7521 & 0,7122 & 0,3057 & 0,4065 \\
\hline 100 & 5,5070 & 1,0889 & 0,3759 & 0,7130 & 1,2957 & 0,4054 & 0,8903 & 0,7165 & 0,3078 & 0,4088 \\
\hline
\end{tabular}

Sumber: Hasil Perhitungan

\section{KESIMPULAN}

1. Besarnya arus gangguan hubung singkat dipengaruhi oleh jarak titik gangguan, semakin jauh lokasi gangguan maka arus gangguan hubung singkat akan semakin kecil, begitu pula sebaliknya.

2. Waktu kerja relai di sisi penyulang lebih cepat dibandingkan dengan waktu kerja di incoming dengan selisih waktu (grading time) rata-rata sebesar 0,55 detik. Hal ini disebabkan lokasi gangguan mempengaruhi besar kecilnya selisih waktu (grading time). Semakin jauh jarak lokasi gangguan, maka semakin besar selisih waktu kerja relai di incoming.

\section{DAFTAR PUSTAKA}


[1] Anderson, P.M. 1999. Power System Protection. USA: IEEE Press Power Engineering Series, John Wiley \& Sons, Inc.

[2] Gonen. Turan. 2008. Electric Power Distribution System Engineering. 2nd Edition. Boca Raton: CRC Press Taylor \& Francis Group

[3] Hewitson Leslie, Mark Brown, Ramesh Balakrishnan. 2004. Practical Power System Protection. 1st Edition. Netherlands: Newnes Publications.

[4] Kadarisman, Pribadi., dan Sarimun, Wahyudi. 2012. Koordinasi OCR dan GFR Pada Jaringan distribusi. Jakarta: PT PLN (Persero) Jasa Pendidikan dan Pelatihan.

[5] PT PLN (Persero) P3B Jawa Bali. 2005. Modul Pelatihan Relai OCR. Jakarta: Badan Penerbit PLN.

[6] PT PLN (Persero). 2005. Perhitungan Setting Relai Proteksi Trafo Tenaga. Jakarta: Pusat Pendidikan dan Pelatihan PLN.

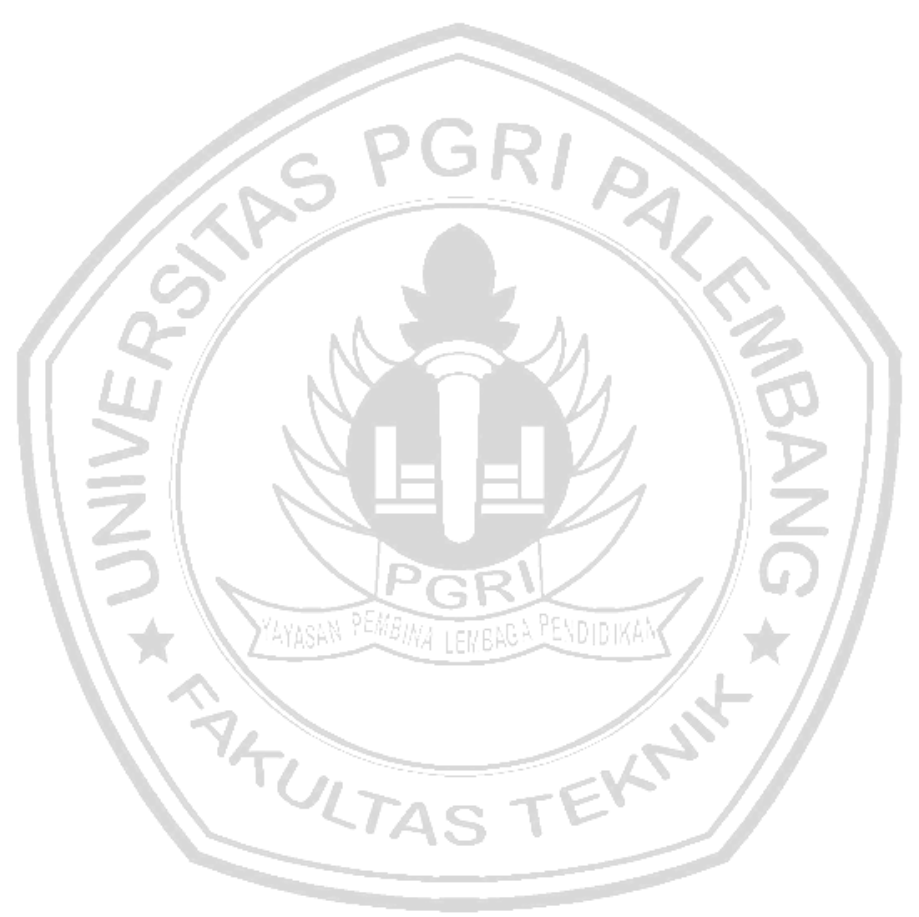

